\title{
Research Note Constraints faced by banana growers in production of banana in Wardha district of Maharashtra
}

See end of the paper for authors' affiliations

Correspondence to : V.N. ANAP

College of Agriculture, Loni AHMEDNAGAR (M.S.) INDIA Email:vikram.anap@ gmail.com

Paper History :

Received : 30.12.2015; Accepted : 30.08 .2016
ABSTRACT : The study aimed at understanding the constraints of banana growers regarding production. The study was conducted in Wardha district in Vidarbha region of Maharashtra state being more concentration of banana cultivation in this district (230 ha). From this district, two tahasil, were purposively selected on the basis of large area under banana production. From these tahasil six villages of banana growers and from each village 15 banana growers were selected for this study. The frequency and percentage of each constraint were worked out to measure the constraint encountered by the respondents. Constraints faced by majority of the respondents were non- availability of electricity in time, losses due to high temperature, fertilizer cost, labour efficiency and other constraints faced by banana growers like lacunae in government policies, subsidies for the banana suckers.

KEY Words : Banana, Banana production, Constraints

How To Cite This PAper : Anap, V.N., Varpe, S.R., Gholap, S.B. and Gaikar, P.S. (2016). Constraints faced by banana growers in production of banana in Wardha district of Maharashtra. Internat. Res. J. Agric. Eco. \& Stat., 7 (2) : 257-259, DOI : 10.15740/HAS/IRJAES/7.2/257-259. 